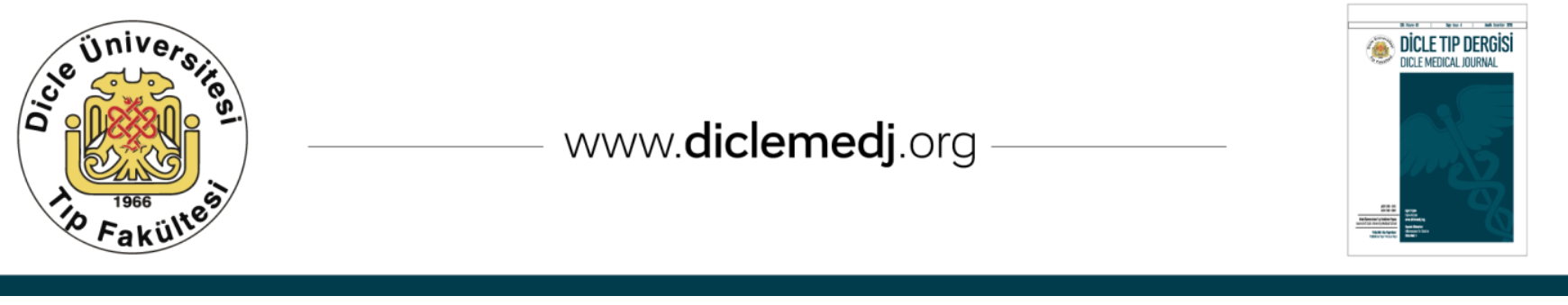

Original Article / Özgün Araştırma

\title{
The Relationship Between MicroRNAs And Congenital Kidney Anomalies
}

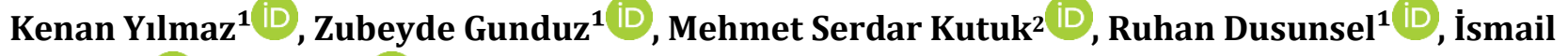 \\ $\operatorname{Dursun}^{1}$ (iD), Sibel Yel ${ }^{1}$ iD
}

1 Department of Pediatric Nephrology, Erciyes University, Kayseri, Turkey 2 Department of Perinatology, Erciyes University, Kayseri, Turkey

Received: 20.12.2019; Revised: 29.01.2020; Accepted: 11.02.2020

\begin{abstract}
Objective: The purpose of this study was to identify diagnostic microRNAs (miRNAs) associated with congenital kidney anomalies.

Methods: Twenty-five healthy pregnant women who were found to have fetal kidney anomaly in the second trimester of their pregnancy at Department of Perinatology, were included in the study. Serum samples were taken from the pregnant women at the moment of diagnosis in the antenatal 20th gestational week, whereas serum samples were taken from the cord blood of babies during birth. There were 11 multicystic dysplastic kidney patients, 6 autosomal recessive polycystic kidney patients, and 8 unilateral hypoplastic kidney patients. Expression of specific miRNAs was monitored using specific primer assays in Real-Time PCR. The expression of the following miRNAs was quantified: miR-17, miR-192, miR-194, miR-204, miR-215, and miR-216.
\end{abstract}

Results: mir-17 expression was significantly lower in children with congenital kidney anomalies than in the control group. ROC curve analysis showed that the area under the curve was 0.700 for miR-17 in the prediction of congenital kidney anomalies.

Conclusions: In children with congenital kidney anomalies, miR-17 expression was significantly different than in the control group. Thus, this miRNA may be used in the antenatal early detection of these congenital kidney anomalies.

Keywords: microRNAs; kidney development; biomarker; prenatal diagnosis; children 


\section{MikroRNA'lar ve Doğuştan Böbrek Anomalileri Arasındaki İlişki}

\section{Öz}

Amaç: Bu çalışmanın amacı, doğuştan böbrek anomalileri ile ilişkili tanısal mikroRNA’ların tespit edilmesidir.

Yöntemler: Perinatoloji bölümünde gebeliklerinin ikinci trimesterinde fetüste böbrek anomalisine sahip olan 25 sağlıklı gebe çalışmaya dahil edildi. Gebeliğin 20. Haftasında tanı anında gebelerden, doğum anında bebeklerin kord kanından serum örnekleri alındı. 11 hastada multikistik displastik böbrek, 6 hastada otozomal resesif polikistik böbrek ve 8 hastada tek taraflı hipoplastik böbrek vardı. Spesifik miRNA'ların ekspresyonu, Real-Time PCR'da spesifik primer analizler kullanılarak izlendi. Aşağıdaki miRNA'ların ekspresyonu ölçüldü: miR-17, miR-192, miR-194, miR-204, miR-215 ve miR216.

Bulgular: mir-17 ekspresyonu doğuştan böbrek anomalisi olan çocuklarda kontrol grubuna göre önemli derecede düşüktü. ROC eğrisi analizi, doğuştan böbrek anomalilerinin öngörülmesinde eğri altındaki alanın miR-17 için 0.700 olduğunu göstermiştir.

Sonuç: Doğuştan böbrek anomalisi olan çocuklarda, miR-17 ekspresyonu kontrol grubundan önemli derecede farklıydı. Bu nedenle, bu miRNA, doğuştan böbrek anomalilerinin antenatal erken tespitinde kullanılabilir.

Anahtar kelimeler: mikroRNA'lar; böbrek gelişimi; biyobelirteç; doğum öncesi tanı; çocuklar.

\section{INTRODUCTION}

Although the pathogenesis of congenital kidney anomalies is not well understood, it is known that a strong genetic predisposition plays a role in its etiology. However, it has also been found that maternal, placental, fetal, and environmental factors also influence nephrogenesis ${ }^{1}$.

The developmental process of the human kidney includes three phases: pronephros, mesonephros, and metanephros. These are followed by ureteric budding, epithelial branching, mesenchymal to epithelial transformation, morphogenesis, and differentiation. MicroRNAs(miRNAs) function as regulators in gene expression during the developmental stages of the kidney. miRNAs are non-protein-coding, single- strand, 20-23 nucleotide RNA molecules that have regulatory roles in various biological phenomena and pathological states. miRNAs are thought to regulate cellular gene expression at the transcriptional and post-transcriptional levels. Since miRNAs can cause nonspecific binding of the target gene, mRNA destruction, and translational inhibition, miRNAs have important roles in controlling gene expression. miRNAs also play a role in the control of various biological phenomena such as development, differentiation, survival, apoptosis, and metabolism. Various studies have found different miRNAs specific to different organs, including the kidney. These miRNAs have been found to play a role in both the nephrogenesis stage and the pathogenesis of renal diseases ${ }^{2}$.

The purpose of this study is to define a new biomarker using kidney-specific miRNAs to detect antenatal fetuses with congenital kidney anomalies.

\section{METHODS}

Twenty-five healthy pregnant women who were found to have fetal kidney anomalies during the second trimester of their pregnancy at Department of Perinatology were included in this study. This study conformed to the Declaration of Helsinki and was approved by the Ethics Committee of Erciyes University (2014/174). All participants in the study were provided with detailed information and informed consent was obtained. Inclusion 
criteria were as follows: healthy pregnant women, patients with multicystic dysplastic kidneys, renal hypoplasia and autosomal recessive polycystic kidney disease in fetal ultrasound. Exclusion criteria were as follows: syndromic fetuses with multiple anomalies, multiple gestation, and pregnant women with renal disease history or pregnancy complications. Serum samples were taken from pregnant women at the moment of diagnosis of renal anomaly at the antenatal 20th gestational week and serum samples were taken from the cord blood of babies during birth. Subsequently, control ultrasonography was performed on the 24th, 28th, 32nd, 34th, and 36th weeks. Similarly, blood samples were taken from 20 healthy pregnant women at the 20th gestational week and from the cord blood of babies at the moment of birth. $5 \mathrm{ml}$ venous blood samples were taken from each of the women and infants and centrifuged for 10 minutes at $4000 \mathrm{rpm}$. Serum samples were transferred to $2 \mathrm{ml}$ Eppendorf tubes and stored at $-80^{\circ} \mathrm{C}$.

The diagnosis and classification of congenital kidney anomalies were made according to the following definitions (3).

Renal hypoplasia: Kidneys with normal residual parenchyma; however, they have smaller calyx, lobules and papilla. The sizes of the kidney are less than 2 standard deviations.

Multicystic dysplastic kidney: Kidney contours are lobular, there are a great number of cysts with different sizes and shapes, cysts are in clusters and unrelated, kidney parenchyma is generally fibrosis and echogenic.

Autosomal recessive polycystic kidney: Characterized with big and echogenic kidneys, multicysts of under $1 \mathrm{~cm}$ and the dilatation of renal collecting ducts, medullary pyramids are hyperechogenic and corticomedullary differentiation is lost.

The levels of miR-17, miR-192, miR-194, miR204, miR-215 and miR-216 miRNAs, which are known to be specific to kidney tissue, were analyzed.

Babies with congenital kidney anomalies were checked for serum creatinine levels and urinary ultrasonography was performed on the 3rd day and one month after they were born. In addition, renal scintigraphy (99mTc-MAG3) was performed during the first month to confirm the accuracy of the diagnoses.

Due to kidney injury, peritoneal dialysis was started on two babies with autosomal recessive polycystic kidney disease diagnosed in the last trimester. However, one of the babies was lost on the eighth postnatal day while the other was lost on the thirteenth day due to respiratory insufficiency and sepsis. Serum creatinine levels of the other babies were normal on the postnatal third day and first month.

\section{miRNA isolation, cDNA synthesis and Real- Time PCR}

miRNA was isolated from $300 \mu$ of serum samples using miRNEASY serum/plasma kit (QİAGEN, cat: 217184) by following the kit protocol. RNA values were analyzed using a NanoDrop ND-1000 spectrophotometer (Nanodrop Technologies). miRNA was stored at -800C. cDNA synthesis was performed using miScript II RT Kit (QIAGEN, cat: 218161). 125 ng of miRNA was used for the cDNA synthesis. Expression of specific miRNAs was monitored using specific primer assays (miScript Primer assay, QIAGEN, cat: 218300) in Real-Time PCR. Expression of the following miRNAs was quantified: miR-17, miR-192, miR-204, miR194, miR-215, miR-216. miR-39 was used for normalization. SYBR Green PCR Master Mix (QIAGEN, cat: 218073), miScript Universal Primer and cDNA were mixed and Real-Time PCR were run using the following protocol: 15' preincubation at 950C, 45 cycles of 15" at 950C, $15 "$ at $550 \mathrm{C}, 15 "$ at $700 \mathrm{C}$. Expression levels were quantified using the standard 2- $\Delta \Delta \mathrm{CT}$ method. 


\section{Statistical Analysis}

Mann-Whitney U test was used to compare expression differences between control and patient groups. Receivers operating characteristic (ROC) curve was used to find the cutoff value, area under the curve (AUC), sensitivity and specificity of miR-17.P values less than 0.05 were defined as statistically significant. All statistical analyses were performed using the SPSS version 22 software package (SPSS, Inc., Chicago, USA).

\section{RESULTS}

The number of children with kidney anomalies and control groups was 25 and 20 respectively. There were 14 (56\%) girls in the group of children with kidney anomalies, while there were $12(60 \%)$ girls in the control group. The group with kidney anomalies was divided into three classes according to the type of anomalies. There were 11 multicystic dysplastic kidney patients, 6 autosomal recessive polycystic kidney patients, and 8 unilateral hypoplastic kidney patients.

None of the mothers developed complications during the pregnancy. Their serum creatinine, blood glucose levels, and arterial blood pressure measurements were normal.

In children with congenital kidney anomalies and healthy control groups, relative level of miR-17 were $0.00894(0-0.366)$ and 0.10365 (0.003-0.807), respectively, as median (minimum-maximum). In children with congenital kidney anomalies, miR-17 was found to be significantly lower when compared to the control group ( $\mathrm{P}=0.033)$ (Figure 1).

There was no significant difference between the control group and children with congenital kidney anomalies in terms of other miRNAs (miR-192, miR-194, miR-204, miR-215, miR216) $(\mathrm{P}>0.05)$.
There was no significant difference in terms of miRNAs when compared to pregnant women and control groups $(\mathrm{P}>0.05)$.

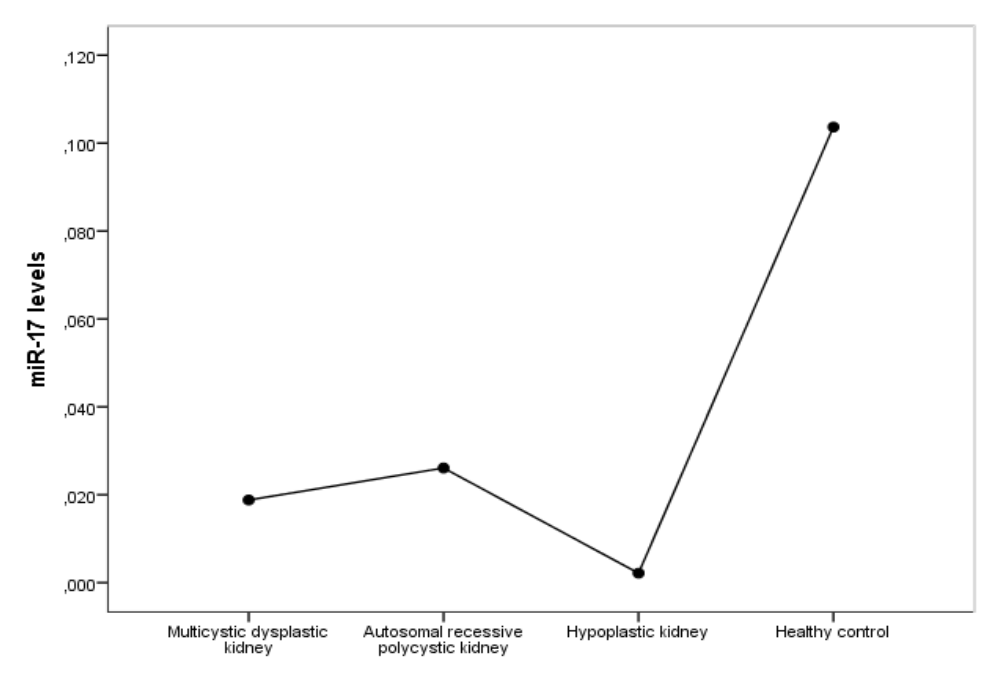

Figure 1: miR-17 levels in children with congenital kidney anomalies and healthy children

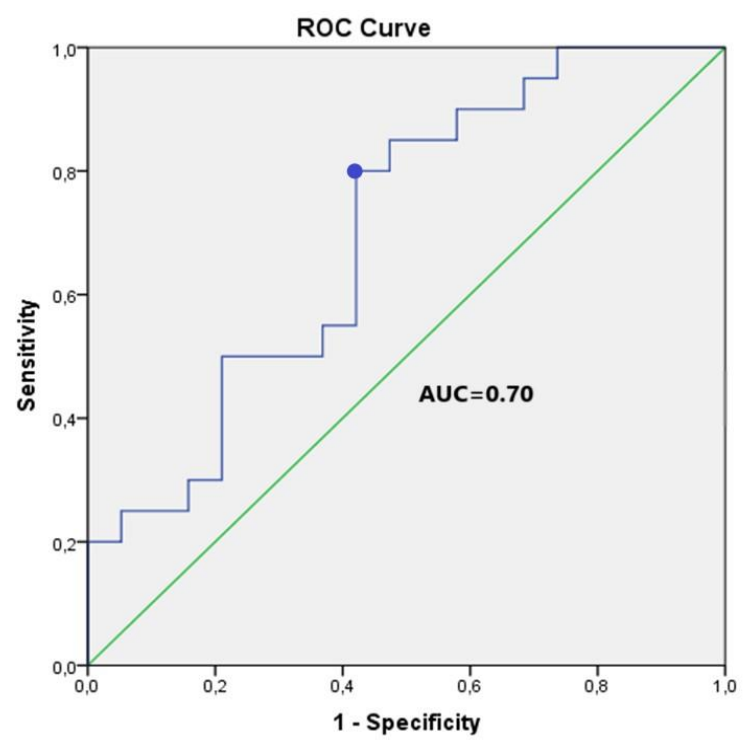

Figure 2: ROC analysis of miR-17 for predicting congenital kidney disease. AUC $=0.70$ ( $95 \%$ confidential interval, $0.53-0.87)$, threshold value $=0.02145$, sensitivity $=0.80$, specificity $=0.58$. ROC, receiver operating characteristic; AUC, area under the curve.

The receiver operating characteristic (ROC) curve analysis indicated that the miR-17 levels 
(AUC $=0.700, \quad$ sensitivity $=80 \%$, specificity $=58 \%$,threshold $\quad$ value $=0.02145$ ) could be a potential diagnostic biomarker to discriminate fetuses with congenital kidney anomalies from healthy subjects (Figure 2).

\section{DISCUSSION}

The development of congenital kidney anomalies involves a complex interaction of genetics and environmental factors. Ultrasonography is currently the only method for the detection of congenital kidney anomalies ${ }^{4}$. The objective of this study was to identify specific biomarkers of congenital kidney anomalies in the early stages of pregnancy with samples taken from the serum of pregnant women.

Kidney development and differentiation occurs as a result of multi-interaction processes, which include transcription factors, growth factors, cell adhesion molecules, cell polarity molecules, renin-angiotensin system compounds, the Wnt signaling pathway, and additional stimulating factors ${ }^{5}$.

It has been determined that many genes contribute to nephrogenesis; however, the complicated process of embryonic kidney formation remains unclear. Fundamentally, nephrogenesis consists of three stages. The first stage, pronephrosis, begins during the fourth week of pregnancy. The second stage, mesonephrosis, begins during the fifth week of pregnancy, and the final stage, metanephrosis, continues the growth of the kidneys until puberty ${ }^{6}$.

miRNAs, which are defined as major regulators of the genome, are promising candidates for new diagnostic and target-specific therapeutic biomarkers in molecular medicine. miRNAs suppress target genes and play a role in processes such as development, differentiation, reproduction, cell death, and apoptosis. miRNAs have been shown to be significant regulators in embryonic stem cells and different miRNA groups have been shown to transform pluripotent stem cells into somatic cells ${ }^{7-10}$.

In addition, miRNAs have been found to have organ-specific roles. When kidneys and other organs are compared, the rarity or absence of specific miRNAs allows the expression of the related target proteins for important functions of the kidney. For example, when compared to other organs, it has been found that higher levels of miR-17, miR-192, miR-194, miR-204, miR-215, and miR-216 are expressed in the kidney and that they are specific to kidney ${ }^{11-13}$. Thus, these six miRNAs were used in our study.

Recently, increasing numbers of studies have found that miRNAs play significant regulatory roles in the development and physiology of the kidneys, in the maintenance of kidney microstructure, and in the course of kidney diseases ${ }^{14,15}$. Further studies are needed to better understand the roles of miRNAs in the developmental process of the kidney.

From the initiation of nephrogenesis, miRNAs play very important roles in kidney development. Kidney development begins when a small group of mesodermal cells turn into nephron progenitors through ureteric budding. Nephron progenitors have been found to be regulated by miRNAs from the early stages of kidney development ${ }^{2}$.

The role of miRNAs in the kidney development process has been investigated in relation to Dicer, which regulates mature miRNA production. Loss of miRNAs in nephron progenitors causes both a decrease in nephron production and the induction of apoptosis in progenitor cells via increased BIM (a proapoptotic protein) levels ${ }^{16}$. Dicer is an enzyme that processes pre-miRNAs into functional miRNA. Thus, miRNAs decrease in the absence of Dicer enzyme. The loss of miRNAs in the ureteric bud resulting from deletion of Dicer causes hypoplastic and cystic kidneys ${ }^{2}$. The 
appearance of cysts in the ureteric epithelium is obvious by embryonic day 15 and is accompanied by increased proliferation, ciliary differentiations, and high levels of apoptosis ${ }^{2,17}$. Numerous studies have examined the potential role of miRNAs in kidney diseases. Some of these studies analyzed differential miRNA expression in kidney diseases, while others investigated specific miRNAs in charge of regulating pathological processes ${ }^{12,13}$.

Recently, various miRNAs have been used as biomarkers for the diagnosis of kidney diseases and have also been found to be associated with the severity of diseases. In particular, it has been shown that miRNAs can be used as biomarkers in lupus nephritis, focal segmental glomerulosclerosis, IgA nephropathy, and diabetic nephropathy ${ }^{18}$.

Autosomal recessive polycystic kidney disease (ARPKD) is a disease with poor prognosis, which generally results in death. ARPKD causes massive renal cysts, abdominal swelling, and pulmonary hypoplasia and secondary to this, respiratory failure. ARPKD is always associated with congenital hepatic fibrosis and less frequently with hepatic cytogenesis, which result from mutations in the PKHD1 gene (that code for fibrocystin) and other ciliary proteins ${ }^{19}$. A study regarding the role of miRNAs in polycystic kidney disease was conducted by Pandey et $a^{20}$ on rats with polycystic kidney disease.

Sun et al. ${ }^{21}$ showed that miR-17 targets PKD2 and plays a role in cytogenesis. In addition, Lee et al. ${ }^{22}$ showed that miR-15a suppresses the expression of $25 \mathrm{~A}$ protein, which regulates cell division in ARPKD, and thus inhibits cell proliferation. The authors showed that miR-15a expression was reduced in both autosomal dominant polycystic kidney disease (ADPKD) and ARPKD.

In a study by Ho et al. ${ }^{23}$, decreasing miRNAs in nephron progenitors caused premature termination of renal development. In particular, the loss of miR-10a, miR-106b, and miR-17-5p was shown to cause increased apoptosis and the suppression of nephron progenitors.

Recently, it has been reported that some miRNAs are correlated with fetal heart diseases. This was determined using peripheral blood samples of pregnant women and these miRNAs were reported to originate in the placenta ${ }^{24-27}$. In light of this information we believe that specific miRNAs found in the cord blood of fetuses can be used as biomarkers for the antenatal early diagnosis of fetal kidney anomalies.

In this study, miR-17 (one of the six miRNAs known to be expressed in high levels in the kidney), was found to be significantly reduced in patients with congenital kidney anomalies. However, there was no significant difference in terms of miRNA values of their mothers.

The threshold value of the miR-17 levels of the patients with congenital kidney disease was calculated. ROC analysis of the miR-17 value for predicting congenital kidney diseases revealed a threshold value of 0.02145 with a sensitivity of $80 \%$ and specificity of $58 \%$.

The interesting aspect of our study is that miRNAs may be used in the detection of fetal kidney anomalies before fetal ultrasound. However, the most important limitation of our study is the small sample size and the fact that only six miRNA types were studied. Thus, further studies involving more patients and the use of different miRNA groups are needed.

In conclusion, the objective of this study was to obtain a biomarker of renal disease in the early phases of pregnancy. Thus, we are of the opinion that miR-17 can be used in the early antenatal diagnosis of congenital kidney anomalies.

This study was supported by the Scientific Research Projects Unit of Erciyes University. 
Ethics Committee Approval: This study conformed to the Declaration of Helsinki and was approved by the Ethics Committee of Erciyes University $(2014 / 174)$.

Declaration of Conflicting Interests: The authors declare that they have no conflict of interest.

Financial Disclosure: No financial support was received.

\section{REFERENCES}

1. Vivante A, Kohl S, Hwang DY, Dworschak GC, Hildebrandt F. Single-genecauses of congenital anomalies of the kidney and urinary tract (CAKUT) in humans. Pediatr Nephrol. 2014; 29: 695-704.

2. Ho J, Kreidberg JA. MicroRNAs in renal development. Pediatr Nephrol. 2013; 28: 21925.

3. Dias T, Sairam S, Kumarasiri S. Ultrasound diagnosis of fetal renal abnormalities. Best Pract Res Clin Obstet Gynaecol. 2014; 28: 403-15.

4. van de Hoek G, Nicolaou N, Giles RH, Knoers $\mathrm{NV}$, Renkema KY, Bongers EM. Functional models for congenital anomalies of the kidney and urinary tract. Nephron. 2015; 129: 62-7.

5. dos Santos Junior AC, de Miranda DM, Simões e Silva AC. Congenital anomalies of the kidney and urinary tract: an embryogenetic review. Birth Defects Res C Embryo Today. 2014; 102: 374-81.

6. Caruana G, Bertram JF. Congenital anomalies of the kidney and urinary tract genetics in mice and men. Nephrology (Carlton). 2015; 20: 30911.

7. Baldassarre A, Felli C, Prantera G, Masotti A. Circulating microRNAs and Bioinformatics Tools to Discover Novel Diagnostic Biomarkers of Pediatric Diseases. Genes (Basel). 2017; 8: 234.

8. Makarova JA, Shkurnikov MU, Turchinovich AA, Tonevitsky AG, Grigoriev AI. Circulating
microRNAs. Biochemistry (Mosc). 2015; 80: 1117-26.

9. Ivey KN, Srivastava D. microRNAs as Developmental Regulators. Cold Spring Harb Perspect Biol. 2015; 7: a008144.

10. Van der Hauwaert C, Savary G, Hennino MF, Pottier N, Glowacki F, Cauffiez C. MicroRNAs in kidney fibrosis. Nephrol Ther. 2015; 11: 474-82.

11. Kito N, Endo K, Ikesue M, Weng H, Iwai N. miRNA Profiles of Tubular Cells: Diagnosis of Kidney Injury. Biomed Res Int. 2015; 2015: 465479.

12. Akkina S, Becker BN. MicroRNAs in kidney function and disease. Transl Res. 2011; 157: 236-40.

13. Badal SS, Danesh FR. MicroRNAs and their applications in kidney diseases. Pediatr Nephrol. 2015; 30: 727-40.

14. Trionfini P, Benigni A, Remuzzi G. MicroRNAs in kidney physiology and disease. Nat Rev Nephrol. 2015; 11: 23-33.

15. Bhatt K, Kato M, Natarajan R. Mini-review: emerging roles of microRNAs in the pathophysiology of renal diseases. Am J Physiol Renal Physiol. 2016; 310: 109-18.

16. Ho J, Pandey P, Schatton T, et al. The proapoptotic protein Bim is a MicroRNA target in kidney progenitors. J Am Soc Nephrol. 2011; 22: 1053-63.

17. Nagalakshmi VK, Ren Q, Pugh MM, Valerius MT, McMahon AP, Yu J. Dicer regulates the development of nephrogenic and ureteric compartments in the mammalian kidney. Kidney Int. 2011; 79: 317-30.

18. Zhao H, Ma SX, Shang YQ, Zhang HQ, Su W. micro RNAs in chronic kidney disease. Clin Chim Acta. 2019; 491: 59-65.

19. Hartung EA, Guay-Woodford LM. Autosomal recessive polycystic kidney disease: a 
hepatorenal fibrocystic disorder with 24. Zhu S, Cao L, Zhu J, et al. Identification of pleiotropic effects. Pediatrics. 2014; 134: 83345. maternal serum microRNAs as novel non20. Pandey P, Brors B, Srivastava PK, et al. Microarray-based approach identifies microRNAs and their target functional patterns in polycystic kidney disease. BMC Genomics. 2008; 9: 624.

21. Sun H, Li QW, Lv XY, et al. MicroRNA-17 posttranscriptionally regulates polycystic kidney disease-2 gene and promotes cell proliferation. MolBiol Rep. 2010; 37: 2951-8.

22. Lee SO, Masyuk $T$, Splinter $P$, et al. MicroRNA15a modulates expression of the cellcycle regulator Cdc25A and affects hepatic cystogenesis in a rat model of polycystic kidney disease. J Clin Invest. 2008; 118: 3714-24.

23. Ho J, Pandey P, Schatton T, et al. The proapoptotic protein Bim is a MicroRNA target in kidney progenitors. J Am Soc Nephrol. 2011; 22: invasive biomarkers for prenatal detection of fetal congenital heart defects. Clin Chim Acta. 2013; 424: 66-72.

25. Song Y, Higgins $\mathrm{H}$, Guo J, et al. Clinical significance of circulating microRNAs as markers in detecting and predicting congenital heart defects in children. J Transl Med. 2018; 2: 42.

26. Wojciechowska A, Braniewska A, KozarKamińska K. MicroRNA in cardiovascular biology and disease. Adv Clin Exp Med. 2017; 26: 865-74.

27. Weber DG, Casjens S, Rozynek $\mathrm{P}$, et al. Assessment of mRNA and microRNA Stabilization in Peripheral Human Blood for Multicenter Studies and Biobanks. Biomark Insights. 2010; 5: 95-102. 